\title{
Thermal response of Moroccan lakes to climatic warming: first results
}

\author{
Soufiane Haddout ${ }^{1, *}$, K.L. Priya ${ }^{2}$ and Michel Boko ${ }^{3}$ \\ ${ }^{1}$ Department of Physics, Faculty of Science, Ibn Tofail University, B.P. 133 Kenitra, Morocco \\ 2 Department of Civil Engineering, TKM College of Engineering, Kollam 691005, India \\ ${ }^{3}$ Laboratory of Climatology, National University of Benin, Cotonou, Benin
}

Received: 1 June 2017; Accepted: 13 November 2017

\begin{abstract}
Water temperature plays a primary role in controlling a wide range of physical, geochemical and ecological processes in lakes, with considerable influences on lake water quality and ecosystem functioning. In this paper, we report on the ability of the one-dimensional lake model to simulate the water temperature of Moroccan lakes, i.e., Sidi Boughaba and Sidi Ali lakes, over a 35 yrs period from 1979 to 2014, affected by climate change and based on a freshwater lake model (FLake). During the study periods, two variables are studied, the epilimnion and metalimnion temperatures. The result analysis shows that epilimnion temperatures increased, while metalimnion temperatures decreased. Additionally, we calculate significant air temperature, wind speed and water temperature variation and illustrate, using a sequential $t$ test analysis of regime shifts (STARS) based on the Rodionov method, a substantial increase in annually averaged of all variables, in response to an abrupt shift in the climate. Schmidt stability showed a significant increase for Sidi Ali Lake and near 0 for Sidi Boughaba Lake. On the other hand, the sensitivity analysis (i.e., one-at-a-time (OAT) method) of the atmospheric variable is discussed. The results show good agreement with water temperature observations that suggests that the predictive model can be used to obtain a firstorder estimation of water temperature in Moroccan lakes. Hence, it is possible to apply this model in other Moroccan lakes to simulate the behavior of temperature and to investigate the potential future warming of the water column in lakes, affected by climate change.
\end{abstract}

Keywords: Moroccan lakes / FLake model / water temperature / regime shifts / sensitivity analysis / metalimnion / epilimnion / climate change

\section{Introduction}

Currently, climate change is considered to be one of the most severe threats to ecosystems around the globe (ACIA, 2004; Rosenzweig et al., 2007). In Africa, temperature increases in the 21 st century are expected to be similar to those of other continents (Fig. 1; Mitchell and Hulme, 2000). Additionally, globally averaged land and ocean surface temperature anomalies have increased over the period from 1850 to 2012 (IPCC, 2014). Monitoring and understanding the effects of climate change pose challenges because of the multitude of responses within an ecosystem and the spatial variation within the landscape. A substantial body of research demonstrates the sensitivity of lakes to climate and shows that physical, chemical, and biological lake properties respond rapidly to climate-related changes (ACIA, 2004; Rosenzweig

\footnotetext{
*Corresponding author: haddout.ens@gmail.com
}

et al., 2007). Fast turnover times from organismal to ecosystem scales in lakes are prerequisite for detecting such rapid changes. Previous studies have suggested that lakes are good sentinels of global climate change because they are sensitive to environmental changes and can integrate changes in the surrounding landscape and atmosphere (Carpenter et al., 2007; Pham et al., 2008; Williamson et al., 2008). However, a more thorough analysis of the potential for lakes to act as sentinels for the rapid rates of current climate change is lacking. Studies of lakes provided some of the early indications of the effects of current climate change on ecosystem structure and function (Schindler et al., 1996; Magnuson et al., 2000; Verburg et al., 2003 ) and the consequences for ecosystem services (O'Reilly et al., 2003). Some climate-related signals are highly visible and easily measurable in lakes. For instance, climate-driven fluctuations in water level have been observed on a broad scale in North America (Williamson et al., 2009a, 2009b), and shifts in the timing of ice formation and thawing reflect climate warming at a global scale (Magnuson et al., 2000). Other 


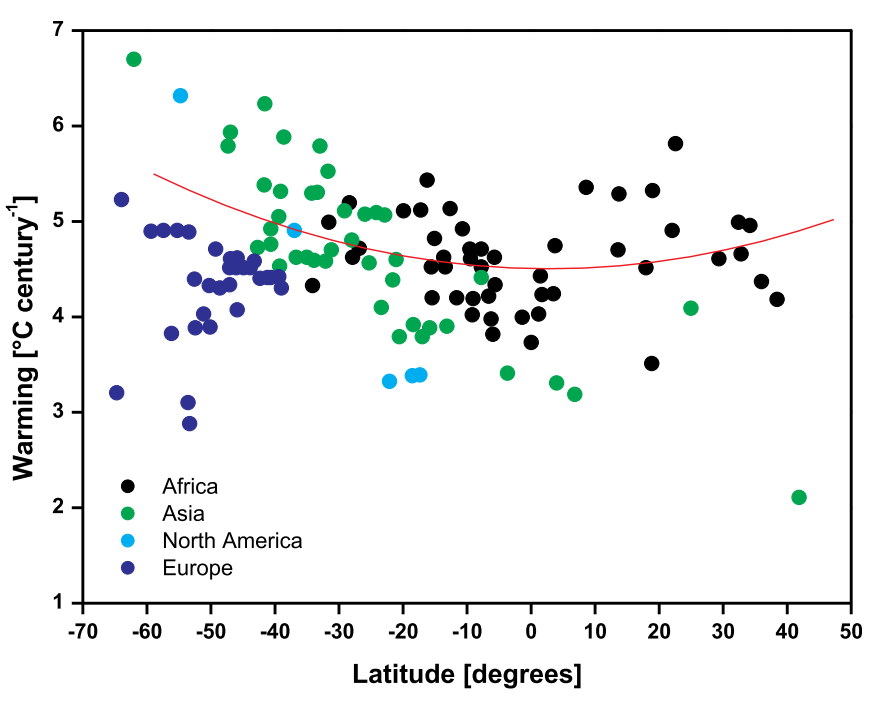

Fig. 1. Mean expected air temperature increases over the 21 st century in 145 countries on four continents. Data from Mitchell and Hulme (2000).

signals may be more complex and difficult to detect in lakes, but they may be equally sensitive indicators of climate forcing or equally informative regarding effects on ecosystem services. Available long-term historical records and reconstructions from sediment cores have yielded insight into less visible climate related changes and provided us with an understanding of the mechanisms that give rise to these changes (Adrian et al., 2009).

Lakes are important sentinels of climate change (Adrian et al., 2009; Williamson et al., 2009a) and the routes to change in lakes include three primary climate forcing pathways: temperature, precipitation, and incident solar radiation (Williamson et al., 2009b). Rising water temperatures in lakes is a particularly important change because lakes have warmed faster than atmospheric temperatures in some cases (Schneider et al., 2009; Schneider and Hook, 2010; Austin and Colman, 2007). Worldwide, the summer surface temperatures of lakes are increasing at an average rate of $0.34{ }^{\circ} \mathrm{C}$ decade $^{-1}$ (O'Reilly et al., 2015). These high rates of temperature rise are likely to have significant effects on lakes because thermal regime has a strong influence on the structure and function of lentic ecosystems (Magnuson et al., 1979; Paerl and Millie, 1996; Lapierre et al., 2015). Specific lake processes that are susceptible to thermal changes include plankton bloom phenology (Williamson et al., 2010), harmful algal blooms (Michalak et al., 2013), depletion of hypolimnion dissolved oxygen concentrations (Jankowski et al., 2006), and thermal suitability for vertebrates (Sharma et al., 2011; Kao et al., 2015). These and other effects of climate change on lakes have been discussed in several recent papers (e.g., Schmid et al., 2014; Woolway et al., 2017a, 2017b, etc.).

On the other hand, the lake physics including temperature and water level, as well as lake chemistry and biological communities, have been or are being affected by these environmental changes (Keller, 2007; Joehnk et al., 2008; Rouse et al., 2008; MacKay et al., 2009; Vincent, 2009; Brown and Duguay, 2010; Brown et al., 2011). To effectively manage lakes and reservoirs in a changing world, quantitative understanding and prediction of the effects of these changes on lake physics are essential (Samal and Mazumdar, 2005). Additionally, the water temperature: surface and epilimnion water temperatures, which can be highly correlated with regional-scale air temperatures, exhibit a rapid and direct response to climatic forcing, making epilimnion temperature a useful indicator of climate change. In many (but no means all) lakes, the epilimnion has undergone recent warming. Epilimnion temperatures are easy to monitor and reflect warming trends in air temperature in North America (Arhonditsis et al., 2004; Coats et al., 2006), Eurasia (Livingstone, 2003; Hampton et al., 2008), and Africa (O'Reilly et al., 2003). In contrast, hypolimnion temperatures exhibit a much more complex behavior, and they may undergo warming or cooling trends depending on lake morphometry (Gerten and Adrian, 2001) and season (Robertson and Ragotzkie, 1990; Livingstone and Lotter, 1998; Straile et al., 2008). Some studies show that the increase in wind speed caused an overall warming of water temperature, with warming in the hypolimnion and metalimnion, but cooling of the epilimnion, especially in summer and autumn, as well as a deeper thermocline and shorter period of stratification (Robertson and Ragotzkie, 1990; Hondzo and Stefan, 1993; Elo et al., 1998; Perroud and Goyette, 2010; Bayer et al., 2013; Palmer et al., 2014; Kraemer et al., 2015; Winslow et al., 2015; Richardson et al., 2017). Additionally, by influencing the density gradient in the water column, vertically heterogeneous changes in water temperature result in long-term changes in the intensity and duration of vertical mixing and stratification, thermal stability, and thermocline depth (Adrian et al., 2009).

Long-term changes in thermal structure might in the future be responsible for mixing regimes shifting from polymictic to dimictic, dimictic to monomictic, or monomictic to oligomictic (Boehrer and Schultze, 2008; Livingstone, 2008). Although long-term changes in thermal structure and mixing regime may require detailed temperature measurements in the water column for their detection, they represent good indicators of climate change because of the directness and sensitivity of their response to climatic forcing. In addition, such long-term physical changes would have severe consequences for nutrient and oxygen concentrations, as well as for the vertical distribution and composition of the biota (Adrian et al., 2009). On the other hand, basin morphometric characteristics such as mean depth, surface area, and volume can strongly affect lake stratification (Butcher et al., 2015; Kraemer et al., 2015; Richardson et al., 2017). Large surface areas increase the effects of vertical wind mixing, an important mechanism for transferring heat to the lake bottom (Rueda and Schladow, 2009) and thermocline shifts may be dampened in large lakes where the depth of the thermocline is constrained by the lake's fetch (Boehrer and Schultze, 2008; MacIntyre and Melack, 2010). Winslow et al. (2015) showed that differences in wind-driven mixing may explain the inconsistent response of hypolimnion temperatures between small and large lakes. While previous research efforts have investigated the response of individual lakes (Austin and Colman, 2007; Voutilainen et al., 2014) and the bulk response of lakes in a geographic region to changing climate (Magnuson et al., 1990; Kirillin, 2010), some studies have focused on elucidating the effects of morphometry, specifically latitude, lake depth and surface area, on changes 
in lake water temperature in response to long-term changes in air temperature and wind speed.

The purpose of this paper is to investigate the response of water temperatures in Moroccan lakes with different morphometry and geography to changing air temperature and wind speed, for the first time. The freshwater lake model (FLake) is a bulk fresh-water lake model and computationally efficient and performs reasonably across lake categories in predicting water temperatures; is used in this paper. Additionally, we calculate significant air temperature, wind speed and water temperature variation and illustrate, using a sequential $t$ test analysis of regime shifts (STARS) based on the Rodionov (2005b) method, a substantial increase in annually averaged of all variables, in response to an abrupt shift in the climate. Schmidt stability showed a significant increase for Sidi Ali lake and $<0.3 \mathrm{~J} \cdot \mathrm{m}^{-2}$ for Sidi Boughaba lake. On the other hand, the sensitivity analysis (SA) of the atmospheric variable is presented. Result analyses show a good-fit between data observations of water temperature and computed water temperature. It is possible to apply this model in other Moroccan lakes to simulate the behavior of temperature and to investigate the potential future warming of the water column in lakes, affected by climate change.

\section{Lake model FLake}

FLake is a bulk fresh-water lake model capable of predicting the water temperature structure and mixing conditions in lakes of various depth on the time scales from a few hours to man years (Mironov, 2008; Mironov et al., 2010). It is based on a two-layer parametric representation of the temperature profile, and on the integral heat and kinetic energy budgets for the layers in question. The structure of the stratified layer between the upper mixed layer and the basin bottom, the lake thermocline, is described using the concept of self-similarity (assumed shape) of the temperature-depth curve. The same concept is used to describe the temperature structure of the ice and snow cover and of the thermally active upper layer of bottom sediments. FLake incorporates an advanced formulation to compute the mixed-layer depth including the equation of convective entrainment and a relaxation-type equation for the depth of a wind-mixed layer, a module to describe the interaction of the water column with bottom sediments, and a snow-ice module. Empirical constants and parameters of FLake are estimated, using independent observational and numerical data. They should not be reevaluated when the model is applied to a particular lake. There are, of course, lake-specific external parameters, such as depth to the bottom and optical properties of water, but these are not part of the model physics. With the integral approach used in FLake, the problem of solving partial differential equations for the temperature and turbulence quantities is reduced to solving ordinary differential equations for the time-dependent quantities that specify the evolving temperature profile. These are mixed-layer temperature and mixed-layer depth, temperature at the water-bottom sediment interface, mean temperature of the water column, shape factor with respect to the temperature profile in the thermocline, temperature at the ice upper surface, and ice thickness. If the bottom sediment module is switched on, two additional prognostic variables are computed, viz., the
Table 1. Morphometric and hydrologic characteristics of the two study Lakes.

\begin{tabular}{lll}
\hline Characteristics & $\begin{array}{l}\text { Lake Sidi } \\
\text { Ali }\end{array}$ & $\begin{array}{l}\text { Lake Sid } \\
\text { Boughaba }\end{array}$ \\
\hline Mean depth [m] & 28.20 & 1.60 \\
Max depth [m] & 43.40 & 2.98 \\
Surface area [ha] & 400 & 650 \\
Shoreline length [km] & 2.20 & 5.50 \\
Groundwater & Ground water & Ground water \\
Station location (from lake [m]) & 200 & - \\
Sampling depth [m] & $0.2-12$ & $0.2-0.4$ \\
Frequency of water temperature & Monthly & Monthly \\
observations & & \\
Longitude & $4^{\circ} 59^{\prime} 43^{\prime \prime} \mathrm{W}$ & $6^{\circ} 39^{\prime} 00^{\prime \prime} \mathrm{W}$ \\
Latitude & $33^{\circ} 04^{\prime} 31^{\prime \prime} \mathrm{N}$ & $34^{\circ} 15^{\prime} 00^{\prime \prime} \mathrm{N}$ \\
Volume $\left[\mathrm{km}^{3}\right]$ & 70 & 10.4 \\
\hline
\end{tabular}

depth of the upper layer of bottom sediments penetrated by the thermal wave and the temperature at that depth (see Mironov (2008), for details). In order to compute fluxes of momentum and of sensible and latent heat at the lake surface, a parameterization scheme is used that accounts for specific features of the surface air layer over lakes. The scheme incorporates a fetch-dependent formulation for the aerodynamic roughness of the water surface, advanced formulations for the roughness lengths for potential temperature and specific humidity in terms of the roughness Reynolds number, and freeconvection heat and mass transfer laws to compute fluxes of scalars in conditions of vanishing mean wind. Further information about FLake can be found at http://lakemodel.net.

\section{Overview of the Moroccans lakes: Sidi Boughaba and Sidi Ali lakes}

Two morphometrically different lakes, lake Sidi Boughaba, and Sidi Ali lake, were selected for this work (see Tab. 1). These lakes are chosen for (1) their morphometry differences, and (2) the availability of long-term of data records for model computed.

1-Sidi Boughaba Lake lies at 3 m.a.s.1 (meters above sea level) in the Atlantic coast of Morocco, located $10 \mathrm{~km}$ South of Kenitra and $1 \mathrm{~km}$ inland from the coast, is the only permanent shallow lake by the Sebou river estuary. Sidi Boughaba surface area $\sim 650$ ha, maximal depth $\sim 2.98 \mathrm{~m}$ (Fig. 2 : left). Due to its shallow depth, Lake Sidi boughaba does not experience thermal stratification in the summer. In addition, this lake is one of the last natural permanent standing bodies on the NorthWest coast of Morocco, most of the other hydro-systems of Gharb plain having been drained and dried. The lake lies in a $\sim 6 \mathrm{~km}$ long depression that separates the coastal mobile dunes (20-30 $\mathrm{m}$ high) and a rim of fossilised dunes ( $\sim 50 \mathrm{~m} \mathrm{high})$ on the east side. A small seasonal daya, adjacent to the Merja Sidi Boughaba, is located in the upper part of the lake basin at its northern rim. During heavy floods, the surface water of this daya flows downward into the merja. The whole 650 ha depression, including both the daya and the merja, was established as a National Natural Reserve of Sidi Boughaba in 

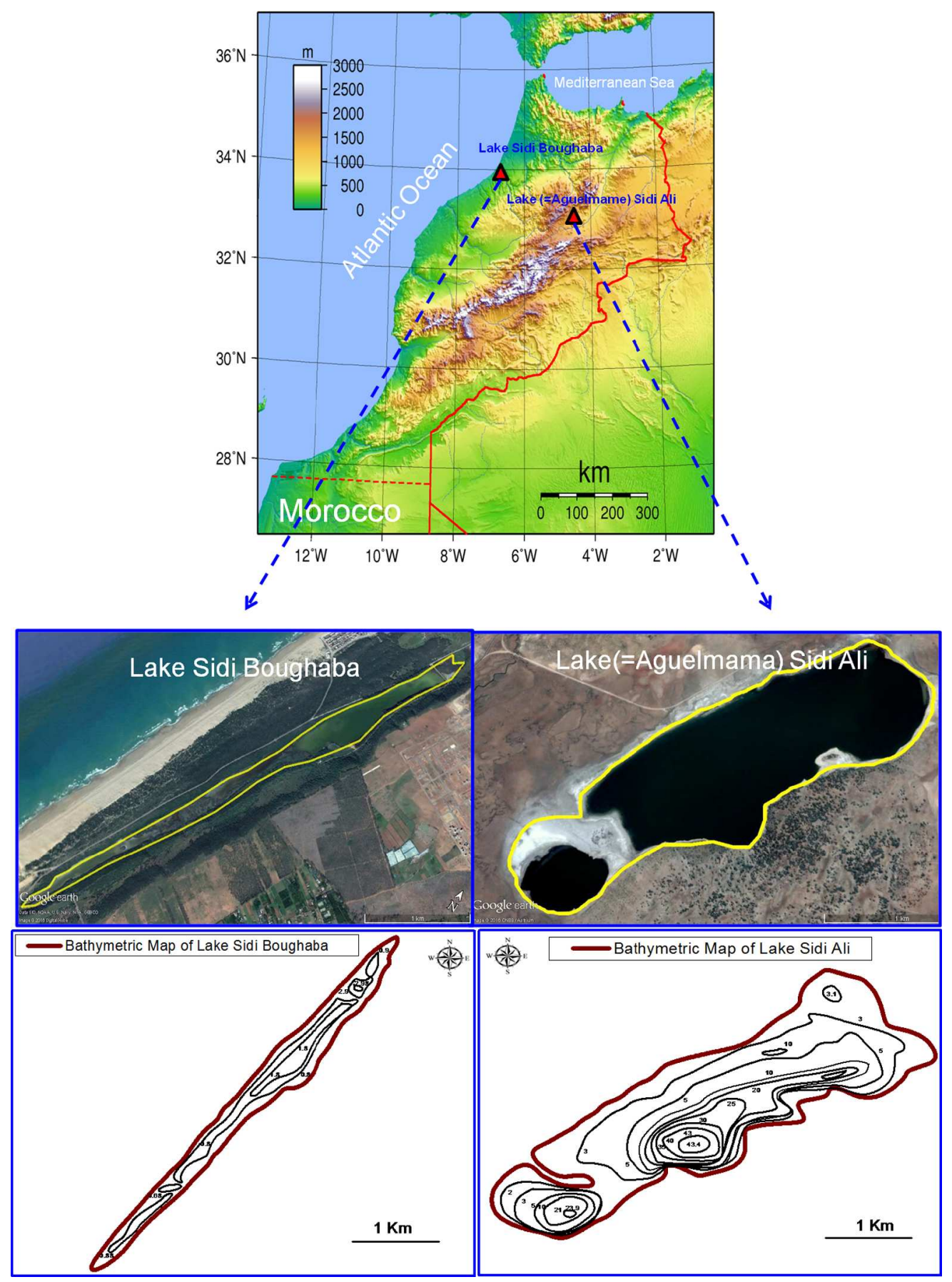

Fig. 2. Location of Lake Sidi Boughaba (Left) and Sidi Ali Lake (Right). Additionally, bathymetric maps for each Lakes.

1975 and was designated as a site of international importance by the Ramsar Convention in 1980. A dense forest of Juniperus phoenicea, Olea europaea, Pistacia lentiscus and Myrthus communis grows on the slopes, thickets of Populus alba encircle the southwestern lake shore (Ramdani et al., 2001) and Ammophila arenaria grows on the mobile dunes (Cherkaoui and Bouchafra, 2003). The lake basin is presently disconnected from both the river and the ocean (Ramdani et al., 2001), so lake water depends on rainfall and groundwater which flow towards the ocean from the Mamora aquifer in a northwestern direction (Zouhri et al., 2004). This aquifer is generally unconfined and rests on a Mio-Pliocene marine blue marl basement, which increases in thickness towards the Atlantic Ocean (60-90 m deep) and is recharged by rainfall infiltration through the very permeable sand and gravels (Zouhri et al., 2004). In addition, the lacustrine sediments consisted grey and black clays, silts, carbonates containing from 20 to $60 \%$ of organic matter (Ramdani, 1981). Salinity measurements during the last decade recorded changes from 2 to $12 \mathrm{~g} \cdot \mathrm{l}^{-1}$ (Ramdani, 1981; Elkhiati, 1987, 1995). In recent years, the southern part of the lake has dried out every summer; in the northern part the water depth has fluctuated between 1.60 
and $2.98 \mathrm{~m}$. The hydrological balance is marked in winter a period of high lake level with low salinity and, during the dry season, by a period of low water level with a strong increase in salinity due to evaporation (Ramdani, 1981; Elkhiati, 1987). On the other hand, Sidi Boughaba area is subject to a Mediterranean climate with Atlantic influence ensuring a yearly rainfall of about $500-600 \mathrm{~mm}$. The Mediterranean climate is characterized by hot dry summers, mild winters and a very variable amount of rainfall from year to year, although there is one certainty: the potential evapotranspiration will exceed rainfall during each and every summer. In North-West Morocco, the Mediterranean climate is influenced by the production by the Atlantic Ocean of a sub-humid Mediterranean climate with mild, moist winters from October until March/April, and hot, dry summers from May until September. In recent decades, average monthly temperatures have ranged from 15 to $28^{\circ} \mathrm{C}$ in the Moroccan town of Mehdia.

2-Sidi Ali Lake lies at 2080 m.a.s.l in the Middle Atlas Mountains of Morocco. Depending on water level fluctuations, the lake may be separated in two sub-basins which are periodically separated by a basalt ridge, as it has been since 1974 (Barker et al., 1994). Sidi Ali lake surface area 400 ha, maximal depth $\sim 43.4 \mathrm{~m}$, is alkaline with a recorded $\mathrm{pH} 9.1$, but is relatively dilute with a conductivity of $12001600 \mu \mathrm{S} \mathrm{cm}^{-1}$ (see Fig. 2: right). The sediments which were collected in 1991 (Barker et al., 1994; El Hamouti, 2003) reveal a rich and varied flora of diatoms but dominated by the genus Cyclotella Sediments core are characterized by horizontally bedded, faintly laminated, calcareous to lime silicic gyttia, with aquatic macrofossils including aquatic plant fragments (Potamogeton) and ostracods rich in diatoms. The lake lies along a fault between Liassic dolomite to the north-west and limestone to the south-east. Gayral (1954) monitored Sidi Ali over an annual cycle and found that during the summer the main lake was well stratified with mean surface temperatures of $20^{\circ} \mathrm{C}$ and mean bottom waters of less than $8^{\circ} \mathrm{C}$, whilst in winter a mean temperature of less than $6^{\circ} \mathrm{C}$ was found at all depths as a result of snowmelt. A similarly stratified dissolved oxygen profile was found by Dumont et al. (1973) who concluded that Sidi Ali was mesotrophic. Water level has fluctuated markedly in recent times, and a shoreline defined by carbonate deposits on basalt was observed $5 \mathrm{~m}$ above the lake level at the time of sampling. Cartographic and air-photograph evidence confirms that tile lakes were joined as recently as 1974 . The vegetation of the area has been described by Lecompte (1986). It includes spiny xerophytic matorral, typified by Erinacea anthyllis Link, with scattered Juniperus thurifera L. An open, heavily degraded forest of Cedrus atlantica (Endl.).

Damp level ground on the southwestern lake margin is occupied by closely grazed herbaceous vegetation, commonly referred to as pelouse. A number of palaeolimnological studies have been recently undertaken in the Middle Atlas region. Chronologically the longest record comes from Tigalmamine, $45 \mathrm{~km}$ southwest of Sidi Ali (Lamb et al., 1989; El Hamouti et al., 1991). This site has revealed water level and vegetation changes during the late Quaternary. Twentieth century water level changes at Lake Azigza, a lake also modulated by groundwater flows, have been shown to correlate with rainfall records (Flower and Foster, 1992). The mean annual precipitation is $430 \mathrm{~mm}$ at Lake Sidi Ali. The dry season lasts from June to September and the wet period from October to May. The position of the lake is within a strong N-S hydrological gradient and reflects a mountainous desert margin between the sub-humid Mediterranean climate in the north and the arid to semiarid High Atlas in the south (Linstadter and Zielhofer, 2010). The lake stratifies during the summer, and a typical stratification period lasts from June to September. During the summer months (June-August), the mean surface water temperature is normally near $19.8^{\circ} \mathrm{C}$, and hypolimnetic temperatures range in value from $5^{\circ} \mathrm{C}$ to $10^{\circ} \mathrm{C}$; however, some years do not experience complete mixing in the spring and reach temperatures of only $4.5-6^{\circ} \mathrm{C}$ in the bottom waters by the end of the summer.

\section{Atmospheric data}

Meteorological data needed to run FLake are solar radiation, air temperature, air humidity, wind speed and cloudiness (0-1), etc. The FLake model is designed such that it can run only on the input of meteorological data. Meteorological data and water temperature observations was gathered from Hydraulic Basin of Sebou Agency (ABHS), who compiled a continuous daily meteorological dataset for Sidi Ali Lake with more than 30 years of daily recording. It should be noted that all of these parameters are retrieved from the approved report by Hydraulic Basin of Sebou Agency (ABHS, 2007, 2009). The data reliability of these studies (i.e., ABHS) for e.g., Sidi Ali Lake was already confirmed by Sayad et al. (2011) which was prepared for conservation of wetlands Middle Atlas in Moroccan. Additionally, some periods data measurements based on literature to complete the unmeasured period (e.g., Ramdani, 1981; Ramdani and Tourenq, 1982; Sayad et al., 2011; Lachhab et al., 2013; Harchrass et al., 2012, 2015; Zielhofer et al., 2017) by adjusting for changes in site location (i.e., comparing data from agency with that collected from literature based on statistical test). The water temperature depth observations $0.2-0.4 \mathrm{~m}$ for Sidi Boughaba; and $0.2-8 \mathrm{~m}$ (at epilimnion) and 4-12 $\mathrm{m}$ (at metalimnion=thermocline) depending on period observations (see Tab. 1). The some atmospheric reanalysis data are used and can be obtained from the National Oceanic and Atmospheric Administration (NOOA) http://www.ncdc.noaa.gov/, and from the National Centers for Environmental Prediction (NCEP) http://www.stat. tamu.edu/.

\section{Statistical methods}

To evaluate FLake model performance, we used a number of statistical metrics: root mean squared error (RMSE); mean absolute error (ABSERR); the Nash Sutcliffe modelling efficiency index (EF); the goodness-of-fit $\left(R^{2}\right)$ and the \% of deviation from observed (PBIAS) (see Moriasi et al., 2007; Stehr et al., 2008; Conversa et al., 2015; Haddout et al., 2016, 2017a, b). The closer the values of RMSE and ABSERR to zero, and the $R^{2}$ to unity, the better the model performance is evaluated (El-Nasr et al., 2005). For Percent bias (PBIAS) measures the average tendency PBIAS, expressed as a percentage, of the simulated data to be larger or smaller than their observed counterparts (Gupta et al., 1999). The optimal value of PBIAS is 0 , with low-magnitude values indicating accurate model simulation (Moriasi et al., 2007). Positive values indicate model 
underestimation bias and negative values indicate model overestimation bias (Gupta et al., 1999). The Nash-Sutcliffe EF (Nash and Sutcliffe, 1970) is a normalized statistic that determines the relative magnitude of the residual variance (noise) compared to the measured data variance (information). EF ranges between $-\infty$ and 1 ( 1 inclusive), with $\mathrm{EF}=1$, the closer the model EF efficiency is to 1, the more accurate is the model. Values between 0 and 1 are generally viewed as acceptable levels of performance, whereas values $\leq 0$ indicate unacceptable performance (Moriasi et al., 2007).

\section{Stability indices}

To determining indices of mixing of lakes, the stability indices choose is Schmidt stability.

\subsection{Schmidt stability}

The resistance to mechanical mixing due to the potential energy inherent in the stratification of the water column was first defined by Schmidt (1928) and later modified by Hutchinson (1957). This stability index was formalized by Idso (1973) to reduce the effects of lake volume on the calculation (resulting in a mixing energy requirement per unit area). Various authors have adopted Idso's methodology; Kling (1988) for example, found a range of stability of 0-5784 $\mathrm{J} \mathrm{m}^{-2}$ across 39 West African lakes, while Ferris and Burton (1988) used Schmidt stability to compare seasonal dynamics in Deep Lake, a hypersaline lake in Antartica. The Schmidt stability is given by:

$$
S_{T}=\frac{g}{A_{S}} \int_{0}^{z_{D}}\left(z-z_{v}\right) \rho_{z} A_{z} \partial z
$$

where $g$ is the acceleration due to gravity, $A_{S}$ is the surface area of the lake, $A_{z}$ is the area of the lake at depth $z, z_{D}$ is the maximum depth of the lake, and $z_{v}$ is the depth to the centre of volume of the lake, written as

$$
z_{v}=\int_{0}^{z_{D}} z A_{z} \partial z \int_{0}^{z_{D}} A_{z} \partial z
$$

$S_{T}$ increases due to gradual warming of the surface waters, and as the so-called center of gravity of the system moves deeper into the water column as a result of vertical differences in density.

\section{Sequential regime shift detection method}

There are a number of methods designed for a detection of regime shifts in both the individual time series and entire systems (Rodionov, 2005a). For the overwhelming majority of these methods, however, their performance deteriorates toward the ends of time series. Rodionov (2004) developed a new method, called STARS for short (later renamed to Sequential Regime Shift Detector (SRSD)), and based on a sequential $t$ test analysis that can signal a possibility of a regime shift in real time. Later, the method was expanded to include shifts in the variance using the sequential $F$-test analysis (Rodionov, 2005b). It also received a new name-the SRSD. In this study, the variables were tested on data using a threshold significance level of $p=0.05$ (North et al., 2013; Magee and Wu, 2016; Magee et al., 2016; Woolway et al., 2017a) a Huber weight parameter of 2 and a cut-off length $L=10$ yrs.

\section{Results and analysis}

\subsection{Changes in climatic variables}

Temporal location and statistical significance, of abrupt shifts in annual mean both lakes temperatures and wind speed as detected by the STARS test (Rodionov, 2005b). Statistical significance: $p<0.05 ; p<0.01$.

The yearly average air temperatures and seasonal air temperatures increased for both lakes over the period 19792014 (Fig. 3). Additionally, yearly air temperature increased at a rate of $0.19^{\circ} \mathrm{C}$ decade $^{-1}(p<0.01)$ for Sidi Ali Lake; and at a rate of $0.053^{\circ} \mathrm{C}$ decade $^{-1}(p<0.05)$ for Lake Sidi Boughaba; spring air temperature increased at a rate of $0.179^{\circ} \mathrm{C}$ decade $^{-1}$ $(p<0.01)$ for Sidi Ali Lake and at a rate of $0.26^{\circ} \mathrm{C}$ decade $^{-1}$ $(p<0.01)$ for Lake Sidi Boughaba; summer air temperature increased at a rate of $0.287^{\circ} \mathrm{C}$ decade $^{-1}(p<0.01)$ (Sidi Ali) and at a rate of $0.32^{\circ} \mathrm{C}$ decade $^{-1}(p<0.01)$ (Sidi Boughaba); winter air temperature increased at a rate of $0.108^{\circ} \mathrm{C}$ decade $^{-1}$ $(p<0.05)$ for Sidi Ali and decrease at a rate of $0.19^{\circ} \mathrm{C}$ decade $^{-1}(p<0.01)$ for Lake Sidi Boughaba.

All four sets of data were further analyzed for significant changes in slope and for abrupt changes in mean. Yearly average air temperature showed a significant change in slope from $0.083{ }^{\circ} \mathrm{C}$ to $0.284^{\circ} \mathrm{C}$ (Sidi Ali Lake) occurring in 2010 2014; but seasonal changes in air temperature showed significant changes in slope over the study period: Spring air temperatures did show significant abrupt changes in the mean value in 2007 from $8{ }^{\circ} \mathrm{C}-8.89^{\circ} \mathrm{C}(p<0.01)$; summer air temperature in 1992 from $20.31^{\circ} \mathrm{C}-20.87^{\circ} \mathrm{C}(p<0.05)$; and in 2011 from $20.87^{\circ} \mathrm{C}-23.71^{\circ} \mathrm{C}(p<0.01)$; winter air temperature in 1989 from $11.91{ }^{\circ} \mathrm{C}-10.84^{\circ} \mathrm{C}(p<0.01)$; and in 2008 from $10.84{ }^{\circ} \mathrm{C}$ to $12.01{ }^{\circ} \mathrm{C}(p<0.05)$. For Sidi Boughaba Lake yearly average air temperature showed a significant change in slope from $0.093{ }^{\circ} \mathrm{C}$ to $0.204^{\circ} \mathrm{C}$ occurring in 1994 ; and from $18.01{ }^{\circ} \mathrm{C}$ to $18.2^{\circ} \mathrm{C}$ occurring in 2010 to 2014 , but seasonal changes in air temperature showed significant changes in slope over the study period: Spring air temperatures did show significant abrupt changes in the mean value in 1987 from $20.11^{\circ} \mathrm{C}$ to $22.69^{\circ} \mathrm{C}(p<0.05)$ and in 2011 from $22.69^{\circ} \mathrm{C}$ to $21.36^{\circ} \mathrm{C}(p<0.01)$; summer air temperature in 1989 from $14{ }^{\circ} \mathrm{C}$ to $16.3^{\circ} \mathrm{C}(p<0.05)$; winter air temperature in 1987 from $19.94^{\circ} \mathrm{C}$ to $16.87^{\circ} \mathrm{C}(p<0.05)$; and in 2011 from $19.94{ }^{\circ} \mathrm{C}$ to $19.99^{\circ} \mathrm{C}(p<0.01)$.

Wind speeds for both yearly and seasonal average exhibited significant decreased in trend over the period 1979-2014, was noted, except since 2008-2011 (Fig. 3). Yearly wind speed decreased at a rate of $0.33 \mathrm{~m} \cdot \mathrm{s}^{-1}(p<0.01)$ for Sidi Ali lake and at a rate of $0.27 \mathrm{~m} \cdot \mathrm{s}^{-1}(p<0.01)$ for Sidi Boughaba lake; for both lakes, spring decreased at a rate of $0.23-0.26 \mathrm{~m} \cdot \mathrm{s}^{-1} \quad(p<0.01)$; summer decreased at a rate of $0.20-0.16 \mathrm{~m} \cdot \mathrm{s}^{-1}(p<0.01)$; and winter decreased at a rate of $0.21-0.18 \mathrm{~m} \cdot \mathrm{s}^{-1}(p<0.01)$. Additionally, four sets of wind speed data for Sidi Boughaba and Sidi Ali Lakes showed 

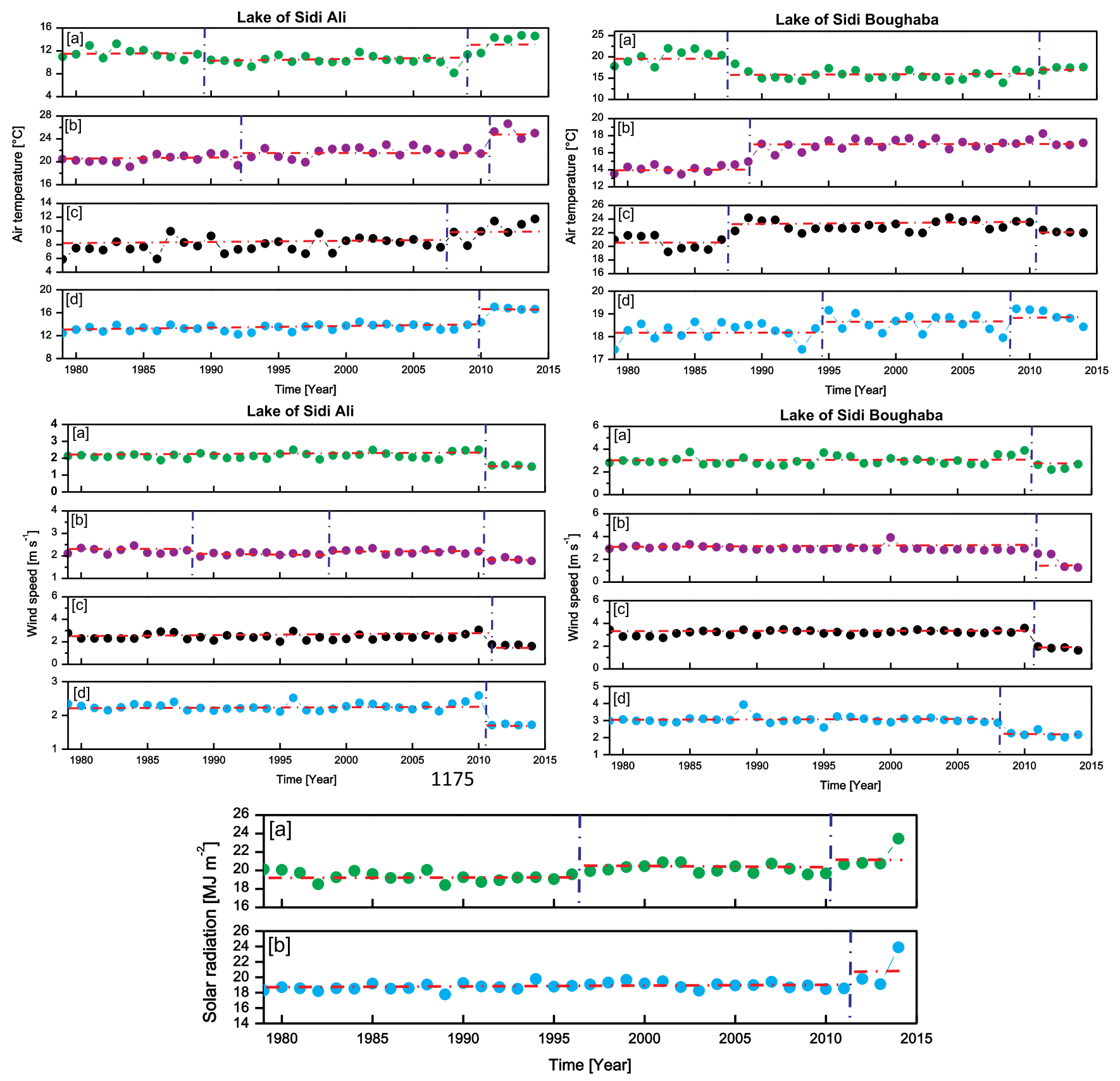

Fig. 3. Winter [Green solid circle [a]], Summer [Violet solid circle [b]], Spring [Black solid circle [c]], and Yearly [Cyan solid circle [d]], air temperature and wind speeds for both lakes Sidi Ali and Sidi Boughaba. Blue lines in yearly, spring, summer, and winter for air temperature and wind speed figures represents abrupt changes in average yearly and each seasons. Additionally, Figure below show, [a] solar radiation for Sidi Ali and [b] for Sidi Boughaba.

significant abrupt changes in the mean value occurring in the 2008-2014. For yearly average wind speed, a shift from $2.58 \mathrm{~m} \cdot \mathrm{s}^{-1}$ to $1.84 \mathrm{~m} \cdot \mathrm{s}^{-1}(p<0.01)$ occurred after 2011 ; for spring wind speeds, a shift from $2.32 \mathrm{~m} \cdot \mathrm{s}^{-1}$ to $1.19 \mathrm{~m} \cdot \mathrm{s}^{-1}$ $(p<0.01)$ occurred after 2012 ; for summer wind speeds, a shift from $2.19 \mathrm{~m} \cdot \mathrm{s}^{-1}$ to $1.97 \mathrm{~m} \cdot \mathrm{s}^{-1}(p<0.01)$ occurred after 2011 and a shift from 1988 and $19982.19 \mathrm{~m} \cdot \mathrm{s}^{-1}$ to $2.00 \mathrm{~m} \cdot \mathrm{s}^{-1}$; for winter, a shift from $2.58 \mathrm{~m} \cdot \mathrm{s}^{-1}$ to $1.86 \mathrm{~m} \cdot \mathrm{s}^{-1}(p<0.01)$ occurred after 2011. For Sid Boughaba Lake, yearly average wind speed, a shift from $3.00 \mathrm{~m} \cdot \mathrm{s}^{-1}$ to $2.5 \mathrm{~m} \cdot \mathrm{s}^{-1}(p<0.01)$ occurred after 2008; for spring wind speeds, a shift from $3.08 \mathrm{~m} \cdot \mathrm{s}^{-1}$ to $2.00 \mathrm{~m} \cdot \mathrm{s}^{-1}(p<0.01)$ occurred after 2011 ; for summer wind speeds, a shift from $3.00 \mathrm{~m} \cdot \mathrm{s}^{-1}$ to $1.98 \mathrm{~m} \cdot \mathrm{s}^{-1}$ $(p<0.01)$ occurred after 2012; for winter, a shift from $3.02 \mathrm{~m} \cdot \mathrm{s}^{-1}$ to $2.96 \mathrm{~m} \cdot \mathrm{s}^{-1}(p<0.01)$ occurred after 2011 .

Regarding, solar radiation showed significant abrupt changes in the mean for Sidi Ali Lake at a rate of $0.98 \mathrm{MJ} \cdot \mathrm{m}^{-2}$ $(p<0.01)$ since 1997 and at a rate of $1 \mathrm{MJ} \cdot \mathrm{m}^{-2}(p<0.01)$ since $2010(p<0.01)$; and at a rate of $1.02 \mathrm{MJ} \mathrm{m}^{-2}(p<0.01)$ since 2012 for Sidi Boughaba Lake (Fig. 3). 


\subsection{Water temperatures}

The yearly average epilimnion temperatures increased for Sidi Ali $0.198^{\circ} \mathrm{C}$ decade $^{-1}$ over the period 1979-2014; and a few variations for Sidi Boughaba Lake $0.013^{\circ} \mathrm{C}$ decade $^{-1}$. Generally, all two lakes have statistically significant $(\mathrm{p}<0.01)$ abrupt changes in mean values over the study period (Fig. 4). For Lake Sidi Ali, there is an abrupt change after 1997 from $22.01{ }^{\circ} \mathrm{C}$ to $22.69^{\circ} \mathrm{C}$ and after 2012 from $24.51{ }^{\circ} \mathrm{C}$ to $25.02^{\circ} \mathrm{C}$. For Lake Boughaba, there is an abrupt change after 1988 from $21.19^{\circ} \mathrm{C}$ to $22.01{ }^{\circ} \mathrm{C}$; and after 1988 from $24.10^{\circ} \mathrm{C}$ to $22.80^{\circ} \mathrm{C}$. The yearly average metalimnion temperatures for Sidi Ali Lake show a few statistically significant increases $0.010^{\circ} \mathrm{C}$ over the period 1979-2014. An abrupt change after 1998 from $11.11^{\circ} \mathrm{C}$ to $11.29^{\circ} \mathrm{C}$ and after 2010 from $11.20^{\circ} \mathrm{C}$ to $11.31^{\circ} \mathrm{C}$ (Fig. 4).

On the other hand, the latitude (i.e., 3 m.a.s.l for Sidi Boughaba and 2080 m.a.s.l for Sidi Ali), surface and depth difference, causes a difference in temperature level. Additionally, for both lakes the combination of increasing air temperatures and decreasing wind speeds yields warmer epilimnion temperatures, lower metalimnion water temperatures (Sidi Ali case).

Regarding, the research on the physical impact of climate change on aquatic systems has tended to focus on gradual longterm trends (e.g., Schneider and Hook 2010), but the present study shows clearly that abrupt changes in large-scale climatic forcing can result in similarly abrupt regime shifts in the physical environments lakes. The impact on aquatic ecosystems of such unannounced and, perhaps, ultimately unpredictable abrupt shifts in physical boundary conditions will likely differ from the impact of more gradual change. Thus, if drastic changes in their functionality are to be avoided, aquatic ecosystems may have to adapt not only to gradual changes in water temperature as climate change progresses, but also to abrupt changes. This emphasizes the importance of maintaining the resilience of aquatic ecosystems in the face of climate change.

\subsection{Lake temperature modeling}

The results of FLake model simulation of water temperature using observational data have been analyzed. Figure 5 shows the monthly historical data of the water temperature, calculated by model versus the data observations for two Moroccans lakes. For well explained, will have two periods in temperature dynamics have been distinguished: the summer period, (JuneAugust), and the winter period, (December-February) for model simulation. The model was validated with all available monthly data for all two lakes during the period 1979-2014, including epilimnion (mixed-layer) and metalimnion (thermocline) layers. The indicators of the model are summarized in Table 2. Table 2 shows, the $\mathrm{EF}$ and $R^{2}$ coefficients are very near to unity $(>0.80)$. The FLake model generally captures well the monthly variability of the water temperature in epilimnion and metalimnion layer for Sidi Ali Lake and in epilimnion layer for Sidi Boughaba Lake. In addition, the first period is characterized by high surface temperatures, while during the second period the surface temperature generally decreases causing convective mixing in the lake.
Epilimnion for Lake Sidi Ali (Fig. 5a and b) were defined as $0-8 \mathrm{~m}$ (mean depth $4 \mathrm{~m}$ ) at summer period and as $0-4 \mathrm{~m}$ (mean depth $2 \mathrm{~m}$ ) during the winter period, based on the surface mixed layer depth from observation and FLake model. For Lake Sidi Boughaba, the whole water column was epilimnion (Fig. 5a and b) because the lake did not stratify during the summer and winter periods. Lake Sidi Ali temperatures ranged from $19.65^{\circ} \mathrm{C}$ to $29.1{ }^{\circ} \mathrm{C}$ (mean $=24.38$ ${ }^{\circ} \mathrm{C}$ ) during the summer period and from $1.98^{\circ} \mathrm{C}$ to $9.1^{\circ} \mathrm{C}$ $\left(\right.$ mean $\left.=5.54^{\circ} \mathrm{C}\right)$ during winter period; and Sidi boughaba Lake temperatures ranged from $17.8^{\circ} \mathrm{C}$ to $25.0^{\circ} \mathrm{C}$ (mean $=$ $21.4{ }^{\circ} \mathrm{C}$ ) during summer period and from $12.8^{\circ} \mathrm{C}$ to $17.0^{\circ} \mathrm{C}$ $\left(\right.$ mean $=14.9^{\circ} \mathrm{C}$ ) during winter period. The two lakes have significant abrupt changes in mean values over the study periods. For Lake Sidi Ali, there is an abrupt change after 1998 from $25^{\circ} \mathrm{C}$ to $28^{\circ} \mathrm{C}$ during summer period and after 2006 from $5.5^{\circ} \mathrm{C}$ to $9.45^{\circ} \mathrm{C}$ during winter period. For Sidi Boughaba there are three shifts: first after 1989 from $21.98^{\circ} \mathrm{C}$ to $24.50^{\circ} \mathrm{C}$, during summer period and after 1982 from $12.4^{\circ} \mathrm{C}$ to $17.5^{\circ} \mathrm{C}$, during winter period.

Regarding, the metalimnion water temperatures for Lake Sidi Ali (Fig. 5c) were defined as 8-15 (mean depth $11.5 \mathrm{~m}$ ) at summer periods and as $4-12 \mathrm{~m}$ (mean depth $8 \mathrm{~m}$ ) at winter period. Metalimnion mean water temperatures for Lake Sidi Ali ranged from $8.3^{\circ} \mathrm{C}$ to $16.7^{\circ} \mathrm{C}$ (mean $=12.2^{\circ} \mathrm{C}$ ).

\subsection{Sensitivity analysis to changes in air temperature and wind speed}

SA techniques can be used to measure the effect on the variation in the model output due to variation in input parameters. Several SA methods exist, including one-at-a-time (OAT) method, fractional experiments, Fourier Amplitude Sensitivity Test (FAST), differential analysis and Sobol'. Generally, OAT (One-Factor-At-A-Time (OAT) method) is the simple technique of screening designs (SD) method to carry out a SA. It consists to identify most sensitive parameter among those may be affecting model output (Nearing et al., 1990). SD is efficient when a model has several input parameter (Jolicoeur, 2002).

In this section, to assess the impact of errors or variation $\pm 10 \%$ around base input value, a SA of the FLake model for water temperature was performed by computing relative variation rate $V_{r}(p)$ and sensitivity index $N S C_{(p)}$ of the air temperature and wind speed variables (i.e., to determine the sensitivity of lake water temperature in response to air temperature and wind speed for both lakes Sidi Ali and Sidi Boughaba) was adopted. Relative variation rate $V_{r}(p)$ and sensitivity index $N S C_{(p)}$ of the FLake model in a parameter $p$, can be expressed as:

$$
\begin{gathered}
V_{r}(p)=\left|\frac{O_{2}-O_{1}}{O_{1}}\right| \cdot 100 \\
N S C_{(p)}=\frac{I_{\text {mean }}}{O_{\text {mean }}} \cdot \frac{O_{2}-O_{1}}{I_{2}-I_{1}}
\end{gathered}
$$



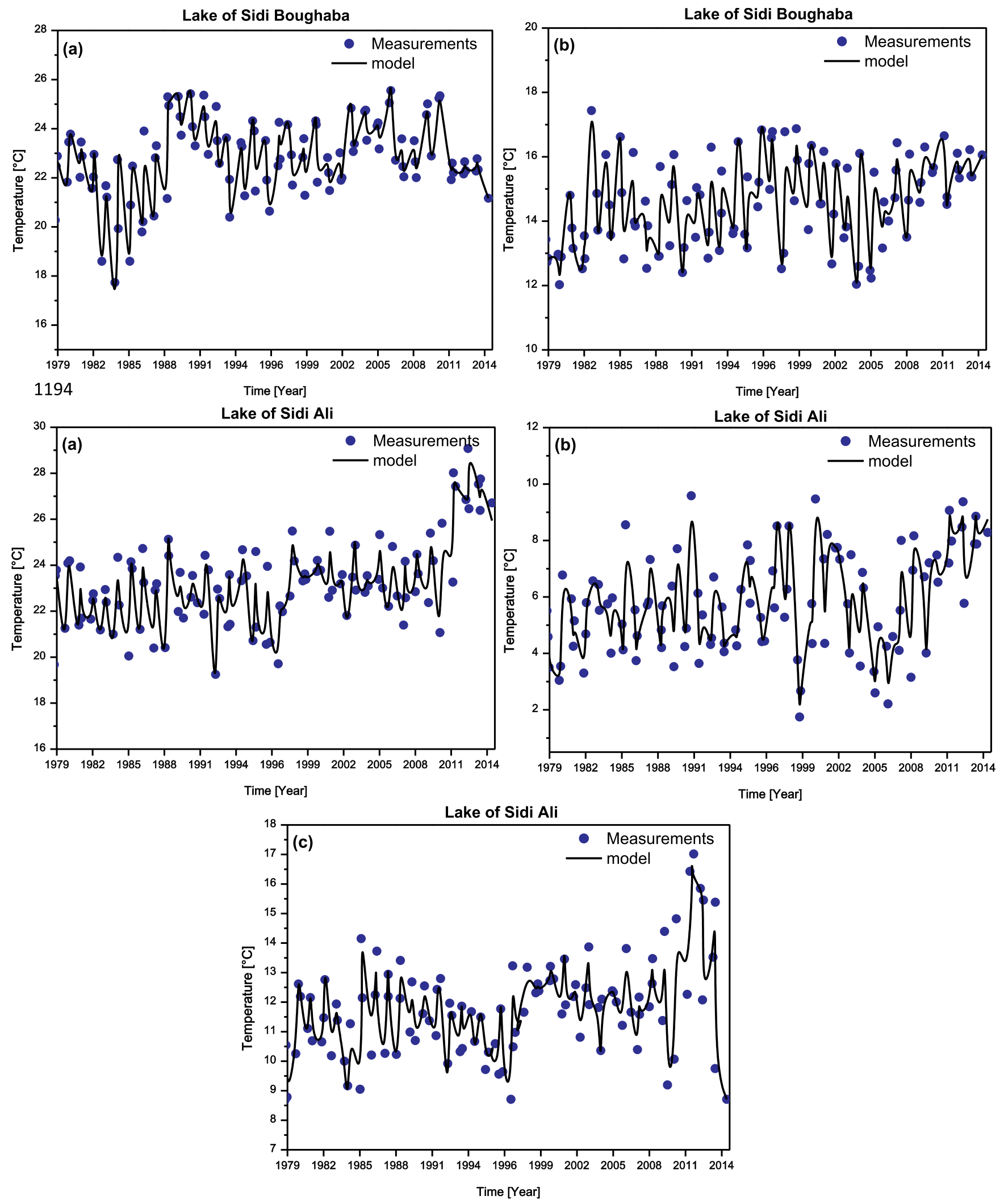

Fig. 4. Comparison of observed and simulated water temperatures for Lake Sidi Boughaba and Sidi Ali Lake. Monthly mean summer (JuneAugust) and winter (December-February) epilimnion temperatures for (a, b) Lake Sidi Boughaba, and (a, b, c) Sidi Ali Lake, and mean summer metalimnion temperatures for Lake Sidi Ali (c). 


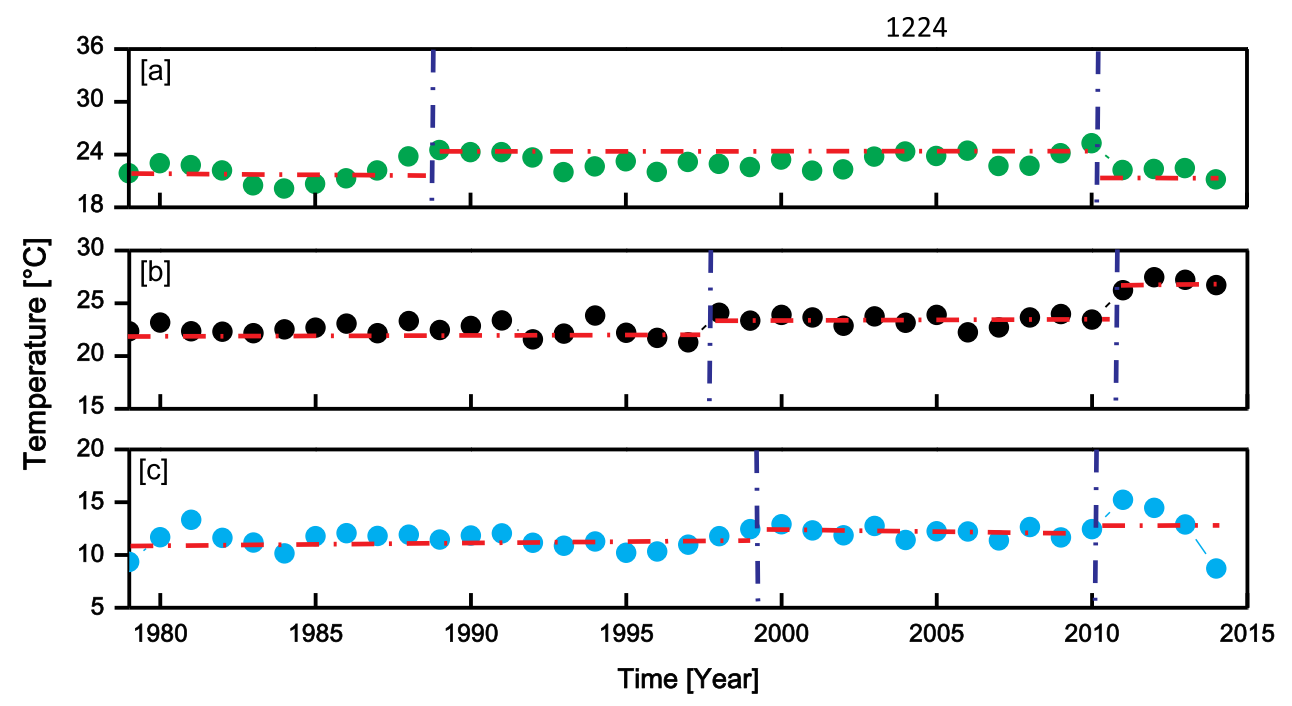

Fig. 5. Mean summertime (June-August) of epilimnion temperatures for (a) Lake Sidi Boughaba, (b) Sidi Ali Lake and mean summertime (June-August) metalimnion temperatures for (c) Lake Sidi Ali. In (a) and (b), dash dot blue lines represent statistically significant $(p<0.5)$ locations of abrupt changes in epilimnion temperatures and dash dot red lines represent mean temperatures for each period. In (c) dash dot blue lines represent metalimnion temperatures for Sidi Ali show few important significant abrupt changes.

Table 2. Statistical indicators of FLake model performance for water temperature variables on Lake Sidi Ali, and Sidi Boughaba Lake. N/A represents errors that cannot be determined because Lake Sidi Boughaba is an epilimnion Lake and does not have a metalimnion. Is a too shallow to develop thermal stratification; thus, their waters can mix from top to bottom (i.e., generally is epilimnion in all vertical water column).

\begin{tabular}{|c|c|c|c|c|c|c|c|c|c|c|}
\hline \multirow[t]{2}{*}{ Variable $\left({ }^{\circ} \mathrm{C}\right)$} & \multicolumn{5}{|c|}{ Lake Sidi Ali } & \multicolumn{5}{|c|}{ Lake Sidi Boughaba } \\
\hline & $\begin{array}{l}\text { RMSE } \\
{\left[{ }^{\circ} \mathrm{C}\right]}\end{array}$ & $\begin{array}{l}\text { ABSERR } \\
{\left[{ }^{\circ} \mathrm{C}\right]}\end{array}$ & $\begin{array}{l}R^{2} \\
{[-]}\end{array}$ & $\begin{array}{l}E F \\
{[-]}\end{array}$ & $\begin{array}{l}\text { PBIAS } \\
{[\%]}\end{array}$ & $\begin{array}{l}\text { RMSE } \\
{\left[{ }^{\circ} \mathrm{C}\right]} \\
\end{array}$ & $\begin{array}{l}\text { ABSERR } \\
{\left[{ }^{\circ} \mathrm{C}\right]}\end{array}$ & $\begin{array}{l}R^{2} \\
{[-]}\end{array}$ & $\begin{array}{l}E F \\
{[-]}\end{array}$ & $\begin{array}{l}\text { PBIAS } \\
{[\%]} \\
\end{array}$ \\
\hline Epilimnion-temperature & 0.31 & 0.38 & 0.90 & 0.92 & 0.68 & 0.33 & 0.28 & 0.89 & 0.88 & 0.94 \\
\hline Metalimnion-temperature & 0.48 & 0.41 & 0.85 & 0.87 & 1.08 & N/A & N/A & N/A & N/A & N/A \\
\hline
\end{tabular}

where $I_{1}$ is the initial input parameter; $I_{2}$ is the tested input value (e.g., $\pm 10 \%$ modification lag); $I_{\text {mean }}$ average between $I_{1}$ and $I_{2} ; O_{1}, O_{2}$ are respectively the outputs corresponding to $I_{1}$ and $I_{2} ; O_{\text {mean }}$ is the average between $O_{1}$ and $O_{2}$. This index provides a quantitative basis for expressing the sensitivity of model outputs versus the input variables. A sensitivity index equal to unity indicates that the rate of variation of a given parameter causes the same rate at the outputs, but a negative value indicates that the inputs and outputs vary in opposite directions. The index in absolute value is greater then its impact of a given parameter which might have on a specific output.

The model outputs are treated as follows: (1) in fact, the change of each input variable (e.g., air temperature or wind speed...etc) by $\pm 10 \%$ produces two values for each selected outputs. From these two introduced input values, the greatest variation at a given output is used to calculate its sensitivity index $N S C_{(p)}$ and (2) percentage change and a sensitivity index (Jolicoeur, 2002) are calculated for each output selected above by previous formulas.

Our model SA illustrates that the increase (decrease) in wind speed and air temperature is the key influence on epilimnion temperature for Sidi Ali Lake, i.e., decreasing wind speed, the water temperature decreases at a rate of $0.97^{\circ} \mathrm{C}$ for each $\mathrm{m} \cdot \mathrm{s}^{-1}$ decrease in wind speed and for increasing wind speed, the water temperature increases at a rate of $1.2^{\circ} \mathrm{C}$ for each $\mathrm{m} \cdot \mathrm{s}^{-1}$ increase in wind speed; the relative variation rate $\left(V_{\mathrm{r}(\mathrm{p})}=7.3-7.9 \%\right)$. Regarding, Sidi Boughaba lake the variation of wind speed variable on epilimnion temperature: decreasing wind speed, the water temperature decreases at a rate of $0.63{ }^{\circ} \mathrm{C}$ for each $\mathrm{m} \cdot \mathrm{s}^{-1}$ decrease in wind speed and for increasing wind speed, the water temperature increases at a rate of $1.8^{\circ} \mathrm{C}$ for each $\mathrm{ms}^{-1}$; the relative variation rate $\left(V_{\mathrm{r}(\mathrm{p})}=11.88-8.23 \%\right)$ increase in wind speed (see Tab. 3). As wind speed decreases (increases), the likelihood of the windinduced kinetic energy being sufficient to mix the lake also decreases (increases). On the other hand, the combining the effects of air temperature and wind speed, it suggests that wind speed decreases are a larger driver to metalimnion water temperature changes than increasing air temperatures for lake Sidi Ali relative to Sidi Boughaba lake is a shallow lake that the experience decreasing wind speeds may be more resilient to changing epilimnion temperatures as a result of warmer air temperatures. 


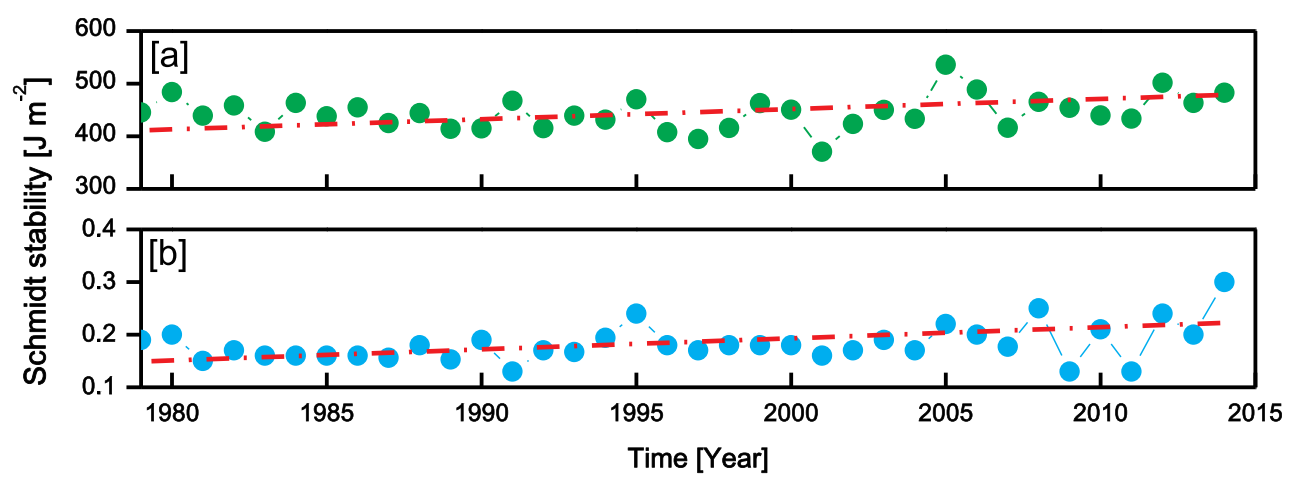

Fig. 6. Yearly average summer-time (June-August) Schmidt stability values for Lake Sidi Ali and Sidi Boughaba Lake.

Table 3. Sensitivity index and Relative variation rate for each variable (Here the asterisk denotes: *Sidi Ali Lake and **Sidi Boughaba Lake).

\begin{tabular}{lccc}
\hline Variable & Wind & Air & Wind \\
& speed & temperature & speed temperature \\
& & Epilimnion & Metalimnion \\
\hline
\end{tabular}

\section{Sensitivity index}

$\operatorname{NSC}_{(p)}(-10 \%) \quad 2.3 * ; 3.19 * * \quad 2.52 * ; 2.71 * * 1.63 * 2.11 *$

$\operatorname{NSC}_{(p)}(+10 \%) 2.5 * ; 2.90 * * \quad 2.76 * ; 3.02 * * 1.72 * 2.07 *$

Relative variation rate

$$
V_{r}(p) \quad 7.3 * ; 11.88 \% * * 7.9 * ; 8.23 \% * * 5.76 \% * 6.60 \% *
$$

\subsection{Lake stability}

For Lake stability, Lake Sidi Boughaba had an average Schmidt stability values about $0.1-0.30 \mathrm{~J} \cdot \mathrm{m}^{-2}$ (Fig. 6), indicating that the lake was easily mixed and polymictic during the summer-winter periods. In contrast, Lake Sidi Ali had significantly higher stability values between 300 and $550 \mathrm{~J} \cdot \mathrm{m}^{-2}$. This lake is stratified and more resistant to mixing.

\subsection{Morphometric effects for two Moroccans Lakes}

\subsubsection{Lakes depth and Lakes surface}

Lakes will respond differently to climate change depending on depths and surface, e.g., Lake Sidi Ali and Sidi Boughaba Lake. Lake Sidi Boughaba, the shallowest of the two, did not stratify, while the deeper lakes, Lake Sidi Ali, did. In addition, Schmidt stability results show a remarkable increase over the long term for Sidi Ali Lake; and no important variation in Lake Sidi Boughaba. Recently, Magee and Wu (2016) shows that the mean lake depths can explain the most variation in stratification trends and lakes with greater mean depths have larger changes in their stability, consistent with our results for Lake Sidi Ali. In deep lakes that stratify, the transition in mixing depth is a key factor in determining the effective heat capacity of the lake (a greater wind speeds are required to completely mix the lake during the summer months, resulting
Table 4. The water surface temperature in reference validated run and in a run with zero heat flux at the lake bottom.

\begin{tabular}{lll}
\hline \multicolumn{3}{c}{ FLake model } \\
\hline & Summer & Winter \\
\hline $\begin{array}{l}\text { Including sediments/soil parameterization } \\
\text { (reference validated run) }\end{array}$ & 1.22 & -0.34 \\
$\begin{array}{l}\text { Excluding sediments parameterization } \\
\text { (zero heat flux at the bottom) }\end{array}$ & 1.10 & -0.41 \\
\hline
\end{tabular}

in more temperature stability and higher Schmidt stability); and lower heat capacity, shallow lakes respond directly to short-term variations in the weather (Arvola et al., 2009; Nõges et al., 2011; Woolway and Merchant, 2017).

On the other hand, for surface; warmer air temperatures result in warmer epilimnion water temperatures, e.g., Sidi Ali Lake. Air temperature is a key factor that controls most of the physical and ecological processes occurring in lakes, and responsible for heat transfer between the atmosphere and lake, is the main driver to epilimnion water temperatures (Boehrer and Schultze, 2008; Palmer et al., 2014). Observed increasing epilimnion water temperature is strongly correlated to the signal of increasing air temperatures (Livingstone, 2003; Robertson and Ragotzkie, 1990). Wind mixing, a more dominant mechanism of heat transfer (Nõges et al., 2011), can act to dampen the effects of air temperature increase and cool the epilimnion through increased surface mixed-layer deepening. As a result, decreasing wind speeds increase epilimnion water temperatures.

\section{Case study: sensitivity of bottom sediments on the water temperature}

Studies were carried out to check whether bottom heat flux indeed played a role in surface water temperature variability during the period of study. In FLake, the sediment layer parameterization can be explicitly switched off, implying a zero heat flux at a lake bottom. Table 4 shows the surface temperature error characteristics, both for reference validated runs and for those neglecting bottom sediments' effects. The weakest sensitivity of the mean mixed-layer temperature to neglecting bottom sediments during the first period was shown by FLake, which produced a few temperature fluctuations than 
in the corresponding reference run. The results of Table 4 can be summarized as follows: In summer bottom sediments impose minor influence on modeled surface temperature due to stable stratification; while the effect of sediments in winter is larger because of complete convective mixing; the error of both periods surface temperature difference can be explained by the lack of a sediment parameterization; these results are explained also by (Stepanenko et al., 2013).

\section{Conclusions}

Thermal water temperatures in two Moroccans morphometrically and geographically different lakes are studied and simulated using a one-dimensional FLake model over the century (1979-2014) to elucidate the effects of increasing air temperature and decreasing wind speed on lake thermal variables. This model requires a minimum amount of information of meteorological data. During the study periods, two variables are chosen are the epilimnion (mixed-layer) and metalimnion (thermocline) temperatures. The results show that epilimnion temperatures increased, while metalimnion temperatures decreased. Additionally, we calculate significant air temperature, wind speed and water temperature variation and illustrate, using a STARS, a substantial increase in annually averaged of all variables, in response to an abrupt shift in the climate. Schmidt stability showed a significant increasing for Sidi Ali and near 0 for Sidi Boughaba Lake. Finally, a good-fit between computed water temperature and observations data is obtained, as verified by statistical performance tests. This model can give a rapid assessment of water temperature evolution and can provide exhaustive information about the thermal structure of lakes, and the impact of future of climate change.

\section{Code availability}

FLake is freely available under the terms of the GNU Lesser General Public License (http:/www.gnu.org/licenses/ lgpl.html). The model source code, external parameter data sets and a comprehensive model description can be obtained from the official FLake website (http://www.lakemodel.net), along with pre-processed meteorological forcing for several test cases. In addition, Regime Shift Detection can be obtained from the official NOAA website (http://www.beringclimate. noaa.gov/regimes/index.html).

Acknowledgements. The authors gratefully acknowledge two anonymous reviewers for their scientific suggestions and constructive comments. Additionally, the authors specifically acknowledge to Prof, Mironov, D, for developing the FLake model. We would like to thank Prof, Festa, $J$ at NOAA's Atlantic Oceanographic and Meteorological Laboratory Miami, for his insightful suggestions and valuable comments. In addition, we thank $D r$, Chen, $Z$ at University of British Columbia, Canada for his insightful suggestions.

\section{References}

ABHS. 2007. Situation hydrologique du Bassin de Sebou, année hydrologique 2006/2007. Bulletin de l'Agence Hydraulique du Bassin du Sebou (ABHS), no. 20, 19 pp.
ABHS. 2009. Situation hydrologique du Bassin de Sebou, année hydrologique 2008/2009. Bulletin de l'Agence Hydraulique du Bassin du Sebou (ABHS), no. 21, 24 pp.

ACIA. 2004. Impacts of a warming Arctic: arctic climate impact assessment, Cambridge University Press, 140 p. Available at: http://www.acia.uaf.edu.

Adrian R, O'Reilly CM, Zagarese H, et al. 2009. Lakes as sentinels of climate change. Limnol Oceanogr 54: 2283.

Arhonditsis GB, Brett MT, DeGasperi CL, Schindler DE. 2004. Effects of climatic variability on the thermal properties of Lake Washington. Limnol Oceanogr 49: 256-270.

Arvola L, George G, Livingstone DM, et al. 2009. The impact of the changing climate on the thermal characteristics of lakes. In: George G, Ed. The Impact of Climate Change on European Lakes. Netherlands: Springer, pp. 85-101, http://link.springer.com/chap ter/10.1007/978-90-481-2945-4 6 (Accessed 29 November 2015).

Austin JA, Colman SM. 2007. Lake Superior summer water temperatures are increasing more rapidly than regional air temperatures: a positive ice-albedo feedback. Geophys Res Lett 34: L06604, DOI:10.1029/2006GL029021.

Barker PA, Roberts N, Lamb HF, Van Der Kaars S, Benkaddour A. 1994. Interpretation of Holocene lake-level change from diatom assemblages in Lake Sidi Ali, Middle Atlas, Morocco. $J$ Paleolimnol 12: 223-234.

Bayer TK, Burns CW, Schallenberg M. 2013. Application of a numerical model to predict impacts of climate change on water temperatures in two deep, oligotrophic lakes in New Zealand. Hydrobiologia 713: 53-71.

Boehrer B, Schultze M. 2008. Stratification of lakes. Rev Geophys 46: 1-27, DOI:10.1029/2006RG000210.

Brown LC, Duguay CR. 2010. The responses and role of ice cover in lake - climate interactions. Prog Phys Geogr 34: 671-703, DOI:10.1177/0309133310375653.

Brown RS, Hubert WA, Daly SF. 2011. A primer on winter, ice, and fish: what fisheries biologists should know about winter ice processes and stream-dwelling fish. Fisheries 36: 8-26, DOI:10.1577/03632415.2011.10389052.

Butcher JB, Nover D, Johnson TE, Clark CM. 2015. Sensitivity of lake thermal and mixing dynamics to climate change. Clim Change 129: 295-305, DOI:10.1007/s10584-015-1326-1.

Carpenter SR et al. 2007. Understanding regional change: a comparison of two lake districts. Bioscience 57: 323-335.

Cherkaoui I, Bouchafra A. 2003. Fiche descriptive sur les zones humides Ramsar (FDR). [Book in French], Wetlands International Publ. Available at: https://www.wetlands.org/

Coats R, Perez-Losada J, Schladow G, Richards R, Goldman C. 2006. The warming of Lake Tahoe. Clim Change 76: 121-148.

Conversa G, Bonasia A, Di Gioia F, Elia A. 2015. A decision support system (GesCoN) for managing fertigation in vegetable crops. Part II-model calibration and validation under different environmental growing conditions on field grown tomato, Frontiers in plant science, Vol. 6.

Dumont HJ, Miron I, Dall'Asta U, Decraemer W, Claus C, Somers D. 1973. Limnological aspects of some Moroccan lakes. Int Revue Ges Hydrobiol 58: 33-60.

El Hamouti N. 2003. Changements Hydrologiques et Climatiques dans le Moyen Atlas marocain depuis $18 \mathrm{Ka} \mathrm{BP}$. à partir de l'étude des diatomées du site de Tigalmamine, Doctorat ès Sciences de l'Université Mohamed I, 300 p., 23 Pls.

El Hamouti N, Lamb H, Fontes J.-Ch, Gasse E. 1991. Changements hydroclimatiques abrupts dans le Moyen Atlas marocain depuis le dernier maximum glaciaire. Comptes-Rendus Acad Sci Paris t. 313 II, 259-265. 
Elkhiati N. 1987. Les Characées (macroalgues) du Maroc: biotypologie dans les eaux continentales et production dans les dayas. Marseille 1: Thèse 3eme cycle, $115 \mathrm{p}$.

Elkhiati N. 1995. Biotypologie et biogéographie des Charophycées du Maroc. Contribution à l'étude des peuplements d'algues et de macrophytes de l'hydrosystème de Tamaris (Meseta occidentale). Marrakech: Thèse d'Etat, Fac. Sci. Semlalia, 155 p.

El-Nasr AA, Arnold JG, Feyen J, Berlamont J. 2005. Modelling the hydrology of a catchment using a distributed and a semi-distributed model. Hydrol Process 19: 573-587.

Elo AR, Huttula T, Peltonen A, Virta J. 1998. The effects of climate change on the temperature conditions of lakes. Boreal Environ Res 3: 137-150.

Ferris JM, Burton HR. 1988. The annual cycle of heat-content and mechanical stability of Deep Lake, Vestfold Hills, Antartica. Hydrobiologia 165: 115-128.

Fink G, Schmid M, Wahl B, Wolf T, Wüest A. 2014. Heat flux modifications related to climate-induced warming of large European lakes. Water Resour Res 50: 2072-2085.

Flower RJ, Foster IDL. 1992. Climatic implications of recent changes in lake level at Lac Azigza (Morocco). Bull Soc Géol France 163: 91-96.

Gayral R. 1954. Recherches phytolimnologiques au Maroc. Trav. Inst. Sci. Ch6rif., Sdr. Bot., Rabat 4: 1-306.

Gerten D, Adrian R. 2001. Differences in the persistency of the North Atlantic Oscillation signalamonglakes.LimnolOceanogr 46:448-455.

Gupta HV, Sorooshian S, Yapo PO. 1999. Status of automatic calibration for hydrologic models: comparison with multilevel expert calibration. J Hydrol Eng 4: 135-143.

Haddout S, Igouzal M, Maslouhi A. 2016. Analytical and numerical study of the salinity intrusion in the Sebou river estuary (Morocco) - effect of the "Super Blood Moon" (total lunar eclipse) of 2015. Hydrol Earth System Sci 20: 3923-3945.

Haddout S, Maslouhi A, Igouzal M. 2017a. Predicting of salt water intrusion in the Sebou river estuary (Morocco). J Appl Water Eng Res 5: 40-50.

Haddout S, Maslouhi A. 2017b. Two-dimensional modeling of the vertical circulation of salt intrusion in the Sebou estuary under different hydrological conditions. ISH J Hydraul Eng 1-18 (in press).

Hampton SE, Izmest E, Lyubov R, et al. 2008. Sixty years of environmental change in the world's largest freshwater lake-Lake Baikal, Siberia. Global Change Biol 14: 1947-1958.

Harchrass A, Elkharrim K, et Belghyti D. 2012. Analyse physicochimiques des eaux du site Ramsar Sidi Boughaba (Maroc). ScienceLib Editions Mersenne 4: 120607.

Harchrass A, Elkharrim K, et Belghyti D. 2015. Analyse en composantes principales (ACP) Des eaux du site Ramsar Sid Boughaba Maroc (Janvier 2012-Décembre 2014). ScienceLib Editions Mersenne 7: 150806.

Hondzo M, Stefan HG. 1993. Regional water temperature characteristics of lakes subjected to climate change. Clim Change 24: 187211, DOI:10.1007/BF01091829.

Hutchinson GE. 1957. A Treatise on Limnology, vol. 1. John Wiley \& Sons, Inc., New York. Idso, SB, 1973. On the concept of lake stability. Limnol Oceanogr 18: 681-683.

Imberger J, Patterson JC. 1990. Physical limnology. Adv Appl Mech 27: 303-475.

IPCC. 2014. Climate Change 2014: Synthesis Report. Contribution of Working Groups I, II and III to the Fifth Assessment Report of the Intergovernmental Panel on Climate Change, Geneva: IPCC, $151 \mathrm{p}$. Jankowski T, Livingstone DM, Buhrer H, Forster R, Niederhauser P. 2006. Consequences of the 2003 European heat wave for lake temperature profiles, thermal stability, and hypolimnetic oxygen depletion: implications for a warmer world. Limnol Oceanogr 51: 815-819, https://doi.org/10.4319/lo.2006.51.2.0815.

Joehnk KD, Huisman J, Sharples J, Sommeijer B, Visser PM, Stroom JM. 2008. Summer heatwaves promote blooms of harmful cyanobacteria. Glob Change Biol 14: 495-512, DOI:10.1111/ j.1365-2486.2007.01510.x.

Jolicoeur B. 2002. Screening designs sensitivity of a nitrate leaching model (ANIMO) using a one-at-a-time method. USA: State University of New York at Binghampton.

Kao Y-C, Madenjian CP, Bunnell DB, Lofgren BM, Perroud M. 2015. Potential effects of climate change on the growth of fishes from different thermal guilds in Lakes Michigan and Huron. $J$ Great Lakes Res 41: 423-435, https://doi.org/10.1016/j.jglr.2015.03.012.

Keller W. 2007. Implications of climate warming for Boreal Shield lakes: a review and synthesis. Environ Rev 15: 99-112, DOI:10.1139/A07-002.

Kirillin G. 2010. Modeling the impact of global warming on water temperature and seasonal mixing regimes in small temperate lakes. Boreal Environ Res 15: 279-293.

Kitaigorodskii S, Miropolski Y. 1970. On the theory of the openocean active layer. - Izv., Atmos Ocean Phys 6: 178-188.

Kling GW. 1988. Comparative transparency, depth of mixing, and stability of stratification in lakes of Cameroon, West-Africa. Limnol Oceanogr 33: 27-40.

Kraemer BM, Anneville O, Chandra S, et al. 2015. Morphometry and average temperature affect lake stratification responses to climate change: lake stratification responses to climate. Geophys Res Lett 42: 4981-4988, DOI:10.1002/2015GL064097.

Lachhab M, Elkharrim K, Elabidi A, Ben akkame R, Belghyti D. 2013. Etude physico-chimique des eaux du lac Sidi Boughaba - Site Ramsar - Kénitra Maroc. ScienceLib Editions Mersenne 5: 131216.

Lamb HF, Eicher U, Switsur VR. 1989. An 18000 year record of vegetation, lake-level and climate history from the Middle Atlas, Morocco. J Biogeogr 16: 65-74.

Lapierre J-F., Seekell DA, del Giorgio PA. 2015. Climate and landscape influence on indicators of lake carbon cycling through spatial patterns in dissolved organic carbon. Glob Change Biol 21: 4425-4435, https://doi.org/10.1111/gcb.13031, PMID: 26150108.

Leavitt PR, et al. 2009. Paleolimnological evidence of the effects on lakes of energy and mass transfer from climate and humans. Limnol Oceanogr 54: 2330-2348.

Lecompte M. 1986. Biog6ographie de la montagne marocaine: le Moyen Atlas central. Paris: CNRS, 202 p.

Linstadter A, Zielhofer C. 2010. Regional fire history shows abrupt responses of Mediterranean ecosystems to centennial-scale climate change (Olea-Pistacia woodlands, NE Morocco). J Arid Environ 74: 101-110.

Livingstone DM. 2003. Impact of secular climate change on the thermal structure of a large temperate central European lake. Clim Change 57: 205-225.

Livingstone DM. 2008. A change of climate provokes a change of paradigm: taking leave of two tacit assumptions about physical lake forcing. Int Rev Hydrobiol 93: 404-414.

Livingstone DM, Lotter AF. 1998. The relationship between air and water temperatures in lakes of the Swiss Plateau: a case study with palæolimnological implications. J Paleolimnol 19: 181-198.

MacIntyre S, Melack JM. 2010. Mixing dynamics in lakes across climatic zones. In: Likens GE, Ed. lake ecosystem ecology: a global perspective. San Diego, CA: Academic Press, 86-95.

MacIntyre S, Fram JP, Kushner PJ, et al. 2009. Climate-related variations in mixing dynamics in an Alaskan arctic lake. Limnol Oceanogr 54: 2401-2417. 
MacKay MD, Neale PJ, Arp CD, et al. 2009. Modeling lakes and reservoirs in the climate system. Limnol Oceanogr 54: 2315-2329, DOI:10.4319/1o.2009.54.6_part_2.2315.

Magee MR, Wu CH. 2016. Response of water temperatures and stratification to changing climate in three lakes with different morphometry. In review.

Magee MR, Wu CH, Robertson DM, Lathrop RC, Hamilton DP. 2016. Trends and abrupt changes in 104 years of ice cover and water temperature in a dimictic lake in response to air temperature, wind speed, and water clarity drivers. Hydrol Earth Syst Sci 20: 1681.

Magnuson JJ, Crowder LB, Medvick PA. 1979. Temperature as an ecological resource. Am Zool 19: 331-343, https://doi.org/10.1093/ $\mathrm{icb} / 19.1 .331$.

Magnuson JJ, Benson BJ, Kratz TK. 1990. Temporal coherence in the limnology of a suite of lakes in Wisconsin, U.S.A. Freshw Biol 23: 145-159, DOI:10.1111/j.1365-2427.1990.tb00259.x.

Magnuson JJ, et al. 2000. Historical trends in lake and river ice cover in the Northern Hemisphere. Science 289: 1743-1746. and Errata 2001, Science 291: 254.

Martin J. 1981. Le Moyen Atlas Central; étude géomorphologique. Notes et Mémoires du service Géologique 28. Ed Serv Géol Maroc Rabat.

Michalak AM, Anderson EJ, Beletsky D, Boland S, Bosch NS, Bridgeman TB, et al. 2013. Record-setting algal bloom in Lake Erie caused by agricultural and meteorological trends consistent with expected future conditions. In: Proceedings, National Academy of Sciences of the United States of America, 110, 6448-6452, https:// doi.,org/10.1073/pnas.1216006110, PMID: 23576718.

Mironov D. 2008. Parameterization of lakes in numerical weather prediction. Description of a lake model, Deutscher Wetterdienst. COSMO Tech Rep 11: 1-41.

Mironov D, Heise E, Kourzeneva E, Ritter B, Schneider N, Terzhevik A. 2010. Implementation of the lake parameterisation saheme FLake into the numerical weather prediction model COSMO. Boreal Environ Res 15: 218-230.

Mitchell TD, Hulme M. 2000. A country-by-country analysis of past and future warming rates. Univ. of East Anglia: Tyndall Centre Working Paper No. 1.

Moriasi DN, Arnold JG, Van Liew MW, Bingner RL, Harmel RD, Veith TL. 2007. Model evaluation guidelines for systematic quantification of accuracy in watershed simulations. Trans Asabe 50: 885-900.

Nash JE, Sutcliffe JV. 1970. River flow forecasting through conceptual models part I-A discussion of principles. J Hydrol 10: 282-290, DOI:10.1016/0022-1694(70)90255-6.

Nearing MA, Deer-Ascough L, Laflen JM. 1990. Sensitivity analysis of the WEPP hillslope profile erosion model. Trans ASAE 33: 839849.

Nõges P, Nõges T, Ghiani M, Paracchini B, Pinto Grande J, Sena F. 2011. Morphometry and trophic state modify the thermal response of lakes to meteorological forcing. Hydrobiologia 667: 241-254, DOI:10.1007/s10750-011-06917.

North RP, Livingstone DM, Hari RE, Köster O, Niederhauser P, Kipfer R. 2013. The physical impact of the late 1980s climate regime shift on Swiss rivers and lakes. Inland Waters 3: 341-350, DOI:10.5268/IW-3.3.560.

O’Reilly CM, Alin SR, Plisnier P.-D, Cohen AS, McKee BA. 2003. Climate change decreases aquatic ecosystem productivity in Lake Tanganyika, Africa. Nature 424: 766-768.

O'Reilly CM, Sharma S, Gray DK, et al. 2015. Rapid and highly variable warming of lake surface waters around the globe. Geophys Res Lett 42, https://doi.org/10.1002/2015g1066235.
Paerl HW, Millie DF. 1996. Physiological ecology of toxic aquatic cyanobacteria. Phycologia 35: 160-167, https://doi.org/10.2216/ i0031-8884-35-6S-160.1.

Palmer ME, Yan ND, Somers KM. 2014. Climate change drives coherent trends in physics and oxygen content in North American lakes. Clim change 124: 285-299.

Perroud M, Goyette S. 2010. Impacts of warmer climate on Lake Geneva water-temperature profiles. Boreal Environ Res 15: 255278.

Pham SV, Leavitt PR, McGowan S, Peres-Nato P. 2008. Spatial variability of climate and land-use effects on lakes of the northern Great Plains. Limnol Oceanogr 53: 728-742.

Ramdani M. 1981. Recherches hydrobiologiques sur la merja Sidi Bou Rhaba (littoral atlantique du Maroc): étude physico-chimique et analyse faunistique. Bulletin de l'Institut Scientifique (Rabat) 5: 37-137.

Ramdani M, Tourenq JN. 1982. Contribution à l'étude faunistique de la Merja de Sidi Boughaba. Bulletin de l'Institut Scientifique, (Rabat) 6: 179-223.

Ramdani M, Flower RJ, Elkhiati N, et al. 2001. North African wetland lakes: characterization of nine sites included in the CASSARINA Project. Aquat Ecol 35: 281-302.

Richardson DC, Melles SJ, Pilla RM, et al. 2017. Transparency, Geomorphology and mixing regime explain variability in trends in lake temperature and stratification across northeastern north America (1975-2014). Water 9: 442.

Robertson DM, Ragotzkie RA. 1990. Changes in the thermal structure of moderate to large sized lakes in response to changes in air temperature. Aquat Sci 52: 360-380, DOI:10.1007/BF00879763.

Rodionov SN. 2004. A sequential algorithm for testing climate regime shifts. Geophys Res Lett 31: L09204, DOI:10.1029/ 2004 GL019448.

Rodionov SN. 2005a. A brief overview of the regime shift detection methods. In: Velikova V, Chipev N, Eds. Large-Scale Disturbances (Regime Shifts) and Recovery in Aquatic Ecosystems: Challenges for Management Toward Sustainability, 14-16 June 2005, Varna, Bulgaria: UNESCO-ROSTE/BAS Workshop on Regime Shifts, pp. 17-24.

Rodionov SN. 2005b. Detecting regime shifts in the mean and variance: methods and specific examples. In: Velikova V, Chipev N, Eds. Large-Scale Disturbances (Regime Shifts) and Recovery in Aquatic Ecosystems: Challenges for Management Toward Sustainability, 14-16 June 2005. Varna, Bulgaria: UNESCO-ROSTE/ BAS Workshop on Regime Shifts, pp. 68-72.

Rosenzweig C. 2007. Assessment of observed changes and responses in natural and managed systems. In: Parry ML, Canziani OF, Palutikof JP, van der Linden PJ, Hanson CE, et al., Eds. Climate change 2007-impacts, adaptation and vulnerability. Contribution of Working Group II to the Fourth Assessment Report of the Intergovernmental Panel on Climate Change. Cambridge Univ. Press, pp. 79-131.

Rouse WR, Oswald CJ, Binyamin N, et al. 2008. The influence of lakes on the regional energy and water balance of the central Mackenzie River Basin. In: Woo MK, Eds. Atmospheric dynamics of a cold region: the Mackenzie GEWEX Study experience, Volume I. New York: Springer, pp. 309-326.

Rueda F, Schladow G. 2009. Mixing and stratification in lakes of varying horizontal length scales: scaling arguments and energy partitioning. Limnol Oceanogr 54: 2003-2017, DOI:10.4319/ lo.2009.54.6.2003.

Samal NR, Mazumdar A. 2005. Management of lake ecosystem. $J$ Ekologia 3: 123-130. 
Sayad A, Chakiri S, Martin C, Bejjaji Z, Echarfaoui H. 2011. Effet des conditions climatiques sur le niveau du lac Sidi Ali (Moyen Atlas, Maroc). Physio-Géo. Géogra phys et Environ 5: 251-268.

Schmidt W. 1928. Über temperatur and stabilitätsverhaltnisse von seen. Geogr Ann 10: 145-177.

Schmid M, Hunziker S, Wüest A. 2014. Lake surface temperatures in a changing climate: a global sensitivity analysis. Clim Change 124: 301-315.

Schneider P, Hook SJ. 2010. Space observations of inland water bodies show rapid surface warming since 1985. Geophys Res Lett 37: $1-5$.

Schindler DW, Bayley SE, Parker BR. 1996. The effects of climatic warming on the properties of boreal lakes and streams at the Experimental Lakes Area, northwestern Ontario. Limnol Oceanogr 41: 1004-1017.

Schneider P, Hook SJ, Radocinski RG, et al. 2009. Satellite observations indicate rapid warming trend for lake in California and Nevada. Geophys Res Lett 36: 1-6, DOI:10.1029/ 2009GL0408461.

Sharma S, Vander Zanden MJ, Magnuson JJ, Lyons J. 2011. Comparing climate change and species invasions as drivers of coldwater fish population extirpations. Plos One 6: DOI:10.1371/ journal.pone.0022906, PMID: 21860661.

Smol JP. 2008. Pollution of lakes and rivers: a paleoenvironmental perspective, 2nd Ed., Blackwell.

Stehr A, Debels P, Romero F, Alcayaga H. 2008. Hydrological modelling with SWAT under conditions of limited data availability: evaluation of results from a Chilean case study. Hydrol Sci J 53: 588-601.

Stepanenko VM, Martynov A, Jöhnk KD, et al. 2013. A onedimensional model intercomparison study of thermal regime of a shallow, turbid midlatitude lake. Geosci Model Dev 6: 1337-1352.

Straile D, Jöhnk K, Rossknecht H. 2008. Complex effects of winter warming on the physiochemical change in the world's largest freshwater lake-Lake Baikal. Siberia. Glob Change Biol 14: 19471958.

Verburg P, Hecky RE, Kling H. 2003. Ecological consequences of a century of warming in Lake Tanganyika. Science 301: 505-507.

Vincent WF. 2009. Effects of climate change on lakes. In: Likens GE, Ed. Encyclopedia of Inland Waters. New York: Academic Press, pp. 55-60.
Voutilainen A, Huttula T, Juntunen J, Rahkola-Sorsa M, Rasmus K, Viljanen M. 2014. Diverging site-specific trends in the water temperature of a large boreal lake in winter and summer due to mixed effects of local features and climate change. Boreal Environ Res 19: 104-114.

Williamson CE, Dodds W, Kratz TK, Palmer M. 2008. Lakes and streams as sentinels of environmental change in terrestrial and atmospheric processes. Front Ecol Environ 6: 247-254.

Williamson CE, Saros JE, Schindler DW. 2009. Sentinels of change. Science 323: 887-889.

Williamson CE, Saros JE, Vincent WF, Smol JP. 2009. Lakes and reservoirs as sentinels, integrators, and regulators of climate change. Limnol Oceanogr 54: 2273-2282, DOI:10.4319/ lo.2009.54.6_part_2.227311.

Williamson CE, Salm C, Cooke SL, Saros JE. 2010. How do UV radiation, temperature, and zooplankton influence the dynamics of alpine phytoplankton communities? Hydrobiologia 648: 73-81, DOI:10.1007/s10750-010-0147-5.

Winslow LA, Read JS, Hansen GJA, Hanson PC. 2015. Small lakes show muted climate change signal in deepwater temperatures. Geophys Res Lett 42: 2014GL062325, DOI:10.1002/ 2014 GL062325.

Woolway RI, Dokulil MT, Marszelewski W, Schmid M, Bouffard D. 2017a. Warming of Central European lakes and their response to the 1980s climate regime shift. Clim Change 142: 505-520, DOI: 10.1007/s10584-017-1966-4.

Woolway RI, Meinson P, Nõges P, Jones ID, Laas A. $2017 \mathrm{~b}$. Atmospheric stilling leads to prolonged thermal stratification in a large shallow polymictic lake. Clim Change 141: 759-773.

Woolway RI, Merchant CJ. 2017c. Amplified surface temperature response of cold, deep lakes to inter-annual air temperature variability. Sci Rep 7: 4130.

Zielhofer C, Fletcher WJ, Mischke S, et al. 2017. Atlantic forcing of Western Mediterranean winter rain minima during the last 12000 years. Quaternary Sci Rev 157: 29-51.

Zouhri L, Gorini C, Deffontaines B, Mania J. 2004. Relationships between hydraulic conductivity distribution and synsedimentary faults, Rharb-Mamora basin, Morocco; Hydrogeological, geostatistical and modeling approaches. Hydrogeol J 12: 591600 .

Cite this article as: Haddout S, Priya KL, Boko M. 2018. Thermal response of Moroccan lakes to climatic warming: first results. Ann. Limnol. - Int. J. Lim. 54: 2 